\title{
Foodborne cereulide causes beta cell dysfunction and apoptosis
}

\author{
Roman Vangoitsenhoven ${ }^{1 *}$, Dieter Rondas ${ }^{1}$, Inne Crèvecoeur ${ }^{1}$, Wannes D'Hertog ${ }^{1}$, Matilde Masini ${ }^{2}$, \\ Mirjana Andjelkovic ${ }^{3}$, Joris Van Loco ${ }^{3}$, Christophe Matthys ${ }^{1}$, Chantal Mathieu', Lut Overbergh', \\ Bart Van der Schueren ${ }^{1}$
}

From Genes and nutrition, is personalised nutrition the next realistic step?

Brussels, Belgium. 25 April 2014

\section{Background}

Environmental factors play a major role in the rising prevalence of type 1 and type 2 diabetes mellitus. Cereulide is a lipophilic peptide that is often found at low concentrations in starchy food. It is a culprit to consider in this era of prepackaged meals.

\section{Materials and methods}

Mouse and rat insulin producing beta cell lines, MIN6 and INS-1E respectively, as well as whole mouse islets, isolated from 2 week old $\mathrm{C} 57 \mathrm{Bl} / 6 \mathrm{~J}$ mice, were exposed to cereulide concentrations ranging from $0.05 \mathrm{ng} / \mathrm{ml}$ to $5 \mathrm{ng} / \mathrm{ml}$ for 24 and 72 h. Cell death was evaluated by a Hoechst/Propidium Iodide assay, and compared to cell death in human hepatocellular HepG2 and monkey fibroblast-like COS-1 cells. Subsequently, MIN6 cells were exposed to low concentrations of cereulide $(0.15-0.5 \mathrm{ng} / \mathrm{ml})$ for $24 \mathrm{~h}$ and glucose-stimulated insulin secretion was evaluated as well as mechanisms of toxicity by mRNA profiling, electron microscopy and caspase activation and cytochrome $\mathrm{c}$ release assay.

\section{Results}

Cereulide exposure caused cell death in MIN6, INS-1E and pancreatic islets, but not in HepG2 or COS-1E cells (Table 1). Caspase 3/7 activation confirmed the apoptotic cell death process. Glucose-stimulated insulin secretion decreased from $10.48 \pm 3.33$ fold to $2.01 \pm 0.51(\mathrm{P}<0.05)$ in MIN6 cells after 24h exposure with $0.25 \mathrm{ng} / \mathrm{ml}$ cereulide. Exposure to $0.25 \mathrm{ng} / \mathrm{ml}$ cereulide induced markers of mitochondrial stress, including PUMA (p53 upregulated modulator of apoptosis; $271 \pm 77 \%$ of control; P $<0.05$ ) but also markers of ER stress, such as CHOP (CCAAT/enhancer-binding protein homologous protein; $641 \pm 190$ $\%$ of control; $\mathrm{P}<0.01$ ). EM revealed swelling and loss of mitochondria, and cytoplasmic cytochrome c release confirmed mitochondrial cell death signalling $(360 \pm 83 \%$ of control after exposure to $0.5 \mathrm{ng} / \mathrm{ml}$ for $24 \mathrm{~h}(\mathrm{P}<0.05)$.

\section{Conclusion}

Cereulide, a toxin frequently found in prepackaged or prepared starchy meals, increases levels of mitochondrial and ER stress markers in beta cells of rats and mice, even

Table 1 Apoptosis induced after $24 \mathrm{~h}$ exposure to cereulide (mean percentage \pm SEM).

\begin{tabular}{llllll}
\hline & MIN6 $(n=5)$ & INS-1E $(n=4)$ & HepG2 $(n=3)$ & COS $(n=3)$ & Islets $(n=3)$ \\
\hline Medium & $7.3 \pm 1.3$ & $2.5 \pm 0.3$ & $5.8 \pm 0.6$ & $1.2 \pm 0.6$ & $3.1 \pm 1.2$ \\
\hline $0.05 \mathrm{ng} / \mathrm{ml}$ cereulide & $5.9 \pm 1.0$ & $3.2 \pm 0.5$ & $6.6 \pm 2.1$ & $1.6 \pm 0.4$ & $3.9 \pm 1.5$ \\
\hline $0.25 \mathrm{ng} / \mathrm{ml}$ cereulide & $31.6 \pm 5.8^{*}$ & $58.1 \pm 11.4^{*}$ & $6.9 \pm 1.5$ & $2.9 \pm 0.7$ & $8.6 \pm 2.4$ \\
\hline $0.5 \mathrm{ng} / \mathrm{ml}$ cereulide & $43.6 \pm 6.1^{*}$ & $100.0 \pm 0.0^{*}$ & $11.9 \pm 2.5$ & $2.6 \pm 0.6$ & $49.2 \pm 9.0$ \\
\hline $5 \mathrm{ng} / \mathrm{ml}$ cereulide & $100.0 \pm 0.0^{*}$ & $100.0 \pm 0.0^{*}$ & $7.7 \pm 2.3$ & $4.3 \pm 0.9$ & $96.4 \pm 3.5^{*}$ \\
\hline
\end{tabular}

${ }^{*} \mathrm{p} \leq 0.05$ vs control

\footnotetext{
* Correspondence: Roman.Vangoitsenhoven@med.kuleuven.be

${ }^{1}$ Clinical and Experimental Medicine and Endocrinology, KU Leuven, Leuven, Belgium
} 
at low doses. In a dose dependent way, it also leads to impaired beta cell function and apoptosis. Cereulide might thus be involved in the current diabetes.

\section{Authors' details}

${ }^{1}$ Clinical and Experimental Medicine and Endocrinology, KU Leuven, Leuven, Belgium. ${ }^{2}$ Department of Translational Research and of New Surgical and Medical Technologies, University of Pisa, Italy. ${ }^{3}$ Food, Medicines, and Consumer Safety, Scientific Institute of Public Health, Brussels, Belgium.

Published: 6 June 2014

doi:10.1186/2049-3258-72-S1-O8

Cite this article as: Vangoitsenhoven et al:: Foodborne cereulide causes beta cell dysfunction and apoptosis. Archives of Public Health 2014

72(Suppl 1):O8

Submit your next manuscript to BioMed Central and take full advantage of:

- Convenient online submission

- Thorough peer review

- No space constraints or color figure charges

- Immediate publication on acceptance

- Inclusion in PubMed, CAS, Scopus and Google Scholar

- Research which is freely available for redistribution

Submit your manuscript at www.biomedcentral.com/submit 